\section{Commentary: What we should know about our learners}

\author{
Shawn S. Groth, MD, MS, ${ }^{a}$ and Ravi Ghanta, $\mathrm{MD}^{\mathrm{b}}$
}

Each generation is shaped by common life experiences that foster a unique set of values, expectations for behavior, and perceptions of the world around us. Naturally, this creates social tension-a proverbial "generational gap," a schism between the ideals and principles of one generation and another. Such a gap has always existed, and failing to navigate it successfully leads to miscommunication and misunderstanding, impairing our ability to function as a highly effective community. As a community of cardiac, thoracic, and congenital surgeons with members at all stages of training and development, we educators from the Baby Boomer Generation and Generation $\mathrm{X}$ must be able to bridge this generational gap to effectually teach our Millennial learners.

In his latest book, Talking to Strangers, Malcolm Gladwell highlights a critical error we make in attempting to understand others, a point that should resonate with all of us educators if we want to connect with our learners. "We do not understand the importance of the context in which the stranger is operating. Don't look at the stranger and jump to conclusions... look at the stranger's world." Like every other generation, the world of Millennials is indeed unique.

The past 4 decades have witnessed technological advances at an exponential pace. Because this period of innovation corresponded with their childhood, as the Council of Economic Advisors noted, "it has shaped the ways that Millennials interact with technology and seems to have affected their expectations for creativity and innovation in their own work lives." " The coronavirus disease 2019 (COVID-19) pandemic has served as a catalyst for changes to medical education, including greater integration of technology such as online

From the Divisions of ${ }^{\mathrm{a}}$ Thoracic Surgery and ${ }^{\mathrm{b}}$ Cardiothoracic Surgery, Michael E. DeBakey Department of Surgery, Baylor College of Medicine, Houston, Tex.

Disclosures: The authors reported no conflicts of interest.

The Journal policy requires editors and reviewers to disclose conflicts of interest and to decline handling or reviewing manuscripts for which they may have a conflict of interest. The editors and reviewers of this article have no conflicts of interest.

Received for publication April 9, 2020; accepted for publication April 10, 2020; available ahead of print April 21, 2020.

Address for reprints: Shawn S. Groth, MD, MS, Division of Thoracic Surgery, Michael E. DeBakey Department of Surgery, One Baylor Plaza, BCM 390, Houston, TX (E-mail: Shawn.Groth@bcm.edu).

J Thorac Cardiovasc Surg 2021;162:342

$0022-5223 / \$ 36.00$

Copyright (c) 2020 by The American Association for Thoracic Surgery

https://doi.org/10.1016/j.jtcvs.2020.04.044

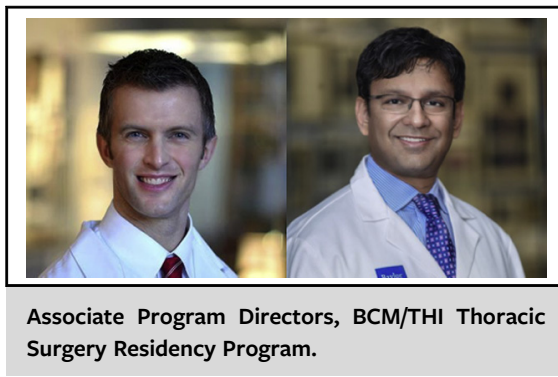

CENTRAL MESSAGE

To be effective educators, we must understand and teach within the social context of the world in which our learners are living and training.

lectures and journal clubs. Nonetheless, we non-Millennials would be painting a shallow brush to presume tech is the only part of the bridge that we need to understand to cross the generational gap. Based on census data, Millennials represent the largest and most diverse post-war generation; many are immigrants or children of immigrants. Although they emphasize the importance of quality of life and personal time, Millennials also value the role they play in their communities, have a strong connection to family and friends, and want to make positive contributions to society. ${ }^{2}$

In this issue of the Journal, Luc and colleagues, who interestingly span several generations, provide an expert opinion on bridging the generational gap between cardiothoracic surgical educators and Millennial learners. ${ }^{3}$ Although all learners are unique, this manuscript provides a high-value blueprint of common generational traits, helping us better understand the social context in which Millennials exist and train, and offers solutions to allow us to be more effective mentors and teachers. Their work is only partially complete. In the near future, Generation $\mathrm{Z}$ learners will be standing across from us in the classroom and operating room. If we want to continue to be effective teachers, we will also have to understand the social context of the world in which they live to help them maximize their potential.

\section{References}

1. Gladwell M. Talking to Strangers: What We Should Know about the People We Don't Know. New York: Hachette Book Group; 2019.

2. The Council of Economic Advisors Executive Office of The President of The United States. 15 Economic Facts About Millenials. Washington, DC: CreateSpace Independent Publishing Platform; October 2014.

3. Luc JGY, Antonoff MB, Vaporciyan AA, Yanagawa B. Surgeon teachers and millennial learners: bridging the generation gap. J Thorac Cardiovasc Surg. $2021 ; 162: 334-41$. 